\title{
Democracy and World Peace: The Kantian Dilemma of US Foreign Policy
}

\author{
John Kane
}

Democracies, according to the findings of political science, do not go to war with one another. A seemingly natural inference from this proposition is that a world populated by democracies will be one of enduring international peace. True moral progress might therefore be measured by the dissemination across the globe of the (presumed universally applicable) liberal democratic values that underpin democratic peace individual rights, government by consent, free commerce and an inclination toward just dealings.

But such thinking raises the question of the kind of foreign policy that democracies ought to pursue in a world still characterised by a great diversity of regime types. It might be expected that such policy should itself be informed by liberal democratic values, and indeed democratic citizens typically demand that their nations' foreign policies adhere to high moral standards. But morally-laden democratic foreign policy tends to encounter a certain dilemma when confronting the exigencies of a complex world, namely that of reconciling idealism and realism. Democracies often feel forced to choose between fulfilling moral imperatives and bowing to political necessities. Good intentions are frequently compromised or undermined by actions in defence of selfish national interests (which invite charges of hypocrisy), ${ }^{1}$ or even by sincere attempts to further the cause of world peace by encouraging democratisation (which provoke accusations of arrogance or naivety).

In this essay I argue that this familiar dilemma is a consequence of the exaggerated divide that liberal democrats tend to presume between moral reason and political action. To understand the nature of this divide, I examine the work of the liberal philosopher who posited it most starkly, Immanuel Kant. Kant is also, of course, the philosopher who first inspired the idea of a democratic peace. Kant hypothesised that perpetual peace would be realised under three conditions: the spread of republican governments around the world; establishment by these of a political federation committed to peaceful coexistence under agreed international law; and acceptance of a right of universal hospitality. A further necessary condition for achieving these, however, was that humanity progress toward a world in which moral reason could have real political effects. This was a matter of some difficulty since, as Kant admitted, self-interestedness made human beings highly resistant to moral motivation. Although he postulated a way in which such virtuous evolution might occur, the account he gave was highly implausible and served only to emphasise the depth of the chasm between idealism and realism. Kant tried to bridge that chasm but could not do so within the bounds of his own theory of morality. Nevertheless, as I will argue, his failed attempt pointed toward a theory of political prudence that alone could solve the idealism-realism dilemma.

I will begin, however, with the practical consequences of this democratic dilemma as regularly demonstrated in United States foreign policy, paying detailed attention to the instructive case of Woodrow Wilson and his failure over the League of Nations covenant. The United States has always distinguished its foreign policy on the grounds of its purported idealism, yet its experience is, I argue, merely a special

\footnotetext{
${ }^{1}$ For example, British liberals were roundly condemned for hypocrisy when their vaunted liberal rationalism turned into liberal imperialism in the nineteenth century (Runciman 2008, 5).
} 
case of a more general liberal democratic phenomenon. America's moral conviction arises from its sense of historic mission to lead the world toward freedom, democracy and peace, but this mission was itself the product of progressive Enlightenment theories whose values pervade all developed democracies.

The foreign policy dilemmas that America has had to negotiate can thus be taken as broadly representative, even if Americans have suffered from them especially acutely. As Inis L. Claude once observed, Americans "undoubtedly place a high value on having - not merely on being thought to have - clean hands and a pure heart; the discomfort of a guilty conscience, or even of nagging uncertainty about one's virtue, is not an easy thing to bear." The unwillingness of the United States to participate in global politics before the twentieth century, he wrote, is due in part to "the dread of dirty hands" (Claude 1986, 731). And certainly Americans have always dwelt, to a degree surprising for citizens of a great power, on their supposed 'innocence' - or what Garry Wills (1987, Ch 41) termed their 'original sinlessness.' Since Americans also believed that power, the main currency of politics, was a source of inevitable corruption, their own use of power would clearly often be in tension with, if not outright contradiction to, moral purity. Americans' resilient belief in their own virtuous intentions could often smother such tensions, but when the contradiction became too glaring to sustain, the result was moral revulsion and political backlash. This happened most painfully in Vietnam, where an escalating but fruitless war caused a near-revolution at home and moral revulsion abroad. Even that doyen of modern realism, Hans Morgenthau, would oppose the Vietnam War because clean hands were impossible in fighting it:

The brutalization of our armed forces would be a serious matter for any nation ... It is intolerable for the United States. For this nation, alone among the nations of the world, was created for a notable purpose: to achieve equality in freedom at home and thereby set an example for the world to emulate.... the world did not expect of us what it had come to expect of others (Morgenthau 1965, 19-20).

The George W. Bush administration's initiation of protracted wars in the Middle East undoubtedly reopened some of the painful moral wounds of Vietnam. The Obama administration has naturally sought to distance its approach from that of its predecessor, but has also tried to do more. It has attempted, in fact, to delineate a foreign policy perspective that permanently evades the old recurring dilemmas by carving out a genuinely prudential American path. Commendable though this is, I will note in conclusion that Obama's experiences reveal just how difficult it is to escape the gravitational pull of the polar division between idealism and realism.

\section{Idealism and realism in US foreign policy}

Jimmy Carter once asserted that idealism and realism must be maintained in careful balance if America is to be true to itself (cited Dumbrell 1995, 2), but such balance has been exceedingly hard to accomplish. Indeed the history of American foreign relations has more the appearance of an extended contest between the forces of each than of a balanced partnership. To understand why this is so, we must recall the European visions of human progress that had such a profound impact in America during the revolutionary period and afterwards. 
Colonists who had initially conceived their argument with the motherland as a defence of traditional British rights found this rationale no longer served once they had declared their independence. The gap was conveniently filled by Enlightenment theories of natural rights and government formed by freely-consenting parties. A struggle for traditional liberties was thus transformed into one for Liberty as such, with Americans cast as the instruments of a benevolent Providence that had placed them in the advance wave of a revolution to liberate the world from the bonds of despotism and social rank-ordering (a vanguard role seemingly confirmed by the outbreak of revolution in France in 1789). ${ }^{2}$ A discord of interests between colonies and motherland had concealed a providential plan, and a local rebellion was now invested with international and indeed universal historical significance. Prominent American historians in the first part of the nineteenth century would weave together the various contingent strands of colonial development, from the Pilgrim Fathers onward, to reveal a hitherto secret narrative of progressive human destiny (Appleby et al. 1995). As the United States struggled first to survive, then to expand, and finally to thrive as a power in the world, its statesmen felt it always incumbent upon themselves to renew allegiance to the nation's benevolent founding mission.

It is important to understand that, although Americans believed themselves 'exceptional' by virtue of this mission, they were exceptional only in having assumed a leadership role for all humankind. If America was, as Madeleine Albright said, the 'indispensible nation,' it was so because it was the 'representative nation,' and what it represented was the liberal, European Enlightenment ideal of moral progress toward a free, peaceful and prospering world of equal nations. ${ }^{3}$ The United States thus constitutes a special case among the family of European liberal democracies and their offspring, all of which inherited, to greater or lesser extents, a set of similar liberal ideals. These ideals also led to certain common dilemmas as they rubbed up against a recalcitrant world. America's foreign policy dilemmas should be regarded, therefore, as liberal democracy's dilemmas writ large, thus providing a peculiarly instructive case for examination.

The liberal democratic ideal that the United States embedded in its central myth of mission was that of a future world composed of free governments pursuing free trade and remaining forever free from the threat of mutual war. The emphasis Americans placed on moral purity was closely attuned to their felt need to preserve this universal mission, one which would arguably be undermined if the United States were seen to act exactly as it observed the powers of the Old World acting - that is, according to the laws of force, fraud and aggrandizement rather than according to laws of equality, respect and justice. To be sure, maintaining certitude in their purity across a century that encompassed international war, civil war, and geographic expansion at the expense of indigenous and Hispanic peoples required, no doubt, a certain wilful blindness on the part of Americans. Nevertheless, as the nation rose to become a world power, its liberal elites felt sufficiently morally secure to contemplate practical moves toward securing peace under international law. ${ }^{4}$ At the dawn of a new

\footnotetext{
${ }^{2}$ Influential British sympathiser and friend of Ben Franklin, Richard Price, argued that, next to the introduction of Christianity, the American Revolution was the most important step in the progressive course of human improvement (Price 1991, 117-118). Seven decades later, William H. Seward (1853-4, vol III, 78) would still be declaring the establishment of the United States government "the most important secular event in the history of the human race."

${ }^{3}$ The title of a book by Henry Steele Commager (1977) says it all: The Empire of Reason: How Europe Imagined and America Realized the Enlightenment.

${ }^{4}$ The very lack of a coercive power in international law made the latter seem superior to domestic law in American eyes, because submission would have to be a matter of pure rational agreement, not of forceful compulsion. As steel magnate and peace champion Andrew Carnegie put it: "International law is unique in one respect. It has no
} 
century, William Jennings Bryan declared that the world under American guidance was on the threshold of a great intellectual and moral awakening in which nations would consider justice more important than physical prowess (cited Osgood 1953, 93).

The Great European war was a massive blow to such hopes, and yet also an opportunity. In 1917 America's president would take the nation into that abhorred war, but only for the stated aim of making the world safe for democracy and, in the post-war settlement, of finally inaugurating the millennial dream of perpetual peace. The philosopher of most relevance here was, of course, Immanuel Kant, who had argued that the three essential conditions for such a peace were: the consolidation of 'civilised peoples' into free republics (whose citizens would surely not, like absolutist monarchs, consent to the burdens and horrors of war except in the most desperate of circumstances); the promulgation of and commitment to international law by a 'league' or 'federation' of free nations (that "does not tend to any dominion over the power of the state but only to the maintenance and security of the freedom of the state itself and of other states in league with it"); and a condition of universal hospitality that would foster the development of peaceful commerce, rendering war unprofitable as well as unpalatable (Kant 1999a). ${ }^{5}$ It seemed obvious to Americans that their nation alone - which had from the start been committed to liberal republican government, free trade and peace - had the moral authority to lay the foundations of the new order. The League of Nations that Wilson envisaged would be what Kant had said it must be: "a league of peace (foedus pacificum) ... distinguished from a treaty of peace (pactum pacis) by the fact that the latter terminates only in war, while the former seeks to make an end of all wars forever" (Kant 1999a). ${ }^{6}$ According to Galston (1975, 26-27), "Woodrow Wilson's Fourteen Points [for negotiating the peace at Versailles] were a faithful transcription of both the letter and spirit of Kant's Perpetual Peace."

Wilson famously failed in his great project, but that was not the end of the matter. A succeeding generation of American leaders would learn from his mistakes and, after another terrible war, invest America's now unrivalled power in the United Nations and assorted supportive economic organisations. In the world order that the United States strove to establish in its moment of opportunity, the facilitation of free commerce would be allied to a program of international economic development to lay the foundations for liberal democracies around the world, fulfilling ultimately all the Kantian conditions for permanent peace. Although severely compromised by the challenge of ideological rivals, as well as morally marred by the experience of Vietnam, this intention was not wholly derailed. With the close of the Cold War, hope sprang immediately to life as it seemed that the 'end of history' - the old history of perpetual conflict - might at last be near.

Alas, this proved not to be the case. Instead the world was plunged into an era of destructive Islamic terrorism that challenged the entire Western ideal; and draining military interventions that were morally divisive as well as unsatisfactory of outcome; financial meltdowns that undermined the economic foundations of the West even as

\footnotetext{
material force behind it. It is a proof of the supreme force of gentleness - the irresistible pressure and final triumph of what is just and merciful" (Carnegie 1933, II, 237).

${ }^{5}$ This at least is Michael Doyle's (1983) rendering of Kant's third article, but see Patapan, this issue. Kant's First Definitive Article for a Perpetual Peace was that "The Civil Constitution of Every State Should Be Republican," the Second that The Law of Nations Shall be Founded on a Federation of Free States," and the Third that "The Law of World Citizenship Shall Be Limited to Conditions of Universal Hospitality" (Kant 1999a).

${ }^{6}$ Kant's essay on Perpetual Peace had a long influence on the liberal internationalism developed in the nineteenth century by figures like British statesmen like George Canning and Lord Palmerston and also by Americans like Wilson.
} 
new powers, most particularly China, seemed inexorably to rise; and uprisings in Middle Eastern tyrannies that raised democratic hopes but fuelled uncertainty regarding regional balances of power. In these conditions, the moral and political leadership of the superpower US (and by association of its democratic allies) was thrown into grave doubt.

And yet the basic moral dilemma affecting US foreign policy was that which Americans had always faced as they struggled to reconcile idealistic expectations and realistic demands. It was always a problem that the United States, although conceiving itself as a universal nation, was also a particular one with its own worldly purposes to pursue, which it generally did with great vigour. This problem was compounded when the US, upon its ascent to dominant 'hegemonic' power status after World War II, acquired additional responsibilities for the interests of its Western allies and dependants, and also for building and maintaining the liberal international economic system that succoured them all.

The tension between professed idealism and an often hard-nosed or merely strategic use of power inevitably led to charges of either naivety or hypocrisy. Thus, on the one hand, the US garnered a reputation as a well-meaning but bumbling intervener in international affairs, its self-proclaimed innocence little more than a cloak for ignorance of the way the world actually works. Such apparently ingenuous idealism was the despair of realists, and indeed the classic works of modern realist authors - Reinhold Niebuhr (1932) or Morgenthau (1948) - were meant as correctives of this unfortunate tendency. The latter criticised United States foreign policy as being subject to the "illusion" that a "nation can escape from power politics into a realm where action is guided by moral principles" (Morgenthau 1951, 131). On the other hand, American idealism often seemed to critics more ideological selfdeception than a spur to moral progress. In the 1820s the Monroe Doctrine was castigated on the grounds that its 'non-colonization principle' (banning European powers from the western hemisphere in order to preserve Latin American experiments in republicanism) was selfishly hypocritical because it applied only to Europeans, leaving Americans free to extend their own internal empire across the continent which could hardly be done with clean hands. As for the international commerce that Americans argued was essential for progress toward world peace, their efforts to spread it abroad, often with force, brought frequent accusations of selfish capitalistic expansion and the establishment of informal American empire. Likewise American championship of liberal democratic values was accused of masking baser motives, as George W. Bush's Iraq invasion was said to be really about oil rather than about democracy and freedom. At the start of the second decade of the twenty-first century, American foreign policy - beset by perceptions of relative decline and failing leadership, and with ideals and realities thrown into hopeless confusion - seemed no nearer escaping this persistent trap.

Yet we must consider the possibility that naivety and hypocrisy are in fact two sides of the same coin (as I will argue a Kantian coin), on one side of which is inscribed the world and its wicked ways, on the other the universe of pure moral intention. If moral action in the world requires a standard divorced from the world and actually impossible of attainment, then belief in moral action is naïve and any pretense to be performing such action hypocritical. The problem of morality and politics may admit of no real solution if the problem has been starkly set as one of either/or: either selfishness or selflessness; either force or law; either interest or duty. As we have indicated, Americans had a persistent tendency to assume a strictly antithetical relationship between morality and power, from which it seemed to follow 
that preserving innocent virtue required withdrawal and a shirking of practical responsibilities ('isolationism'), while engaging the complexities of world politics inevitably required action and compromise that automatically threatened moral purity (Kane 2008). Attempts to actually accomplish idealistic goals produced a foreign policy that was, almost by definition, unrealistic and impractical, while any move toward 'realism' seemed ineluctably to betray cherished ideals.

I will try to demonstrate that the structure of this recurring dilemma is fundamentally Kantian, but before engaging directly with Kant I want to illustrate the problem more precisely with a pertinent case study. I turn therefore to Woodrow Wilson, that most Kantian of American presidents, and his failed negotiations over the League of Nations after World War I.

\section{Wilson and Article $X$}

It is not for nothing that idealism in US foreign policy is often labelled 'Wilsonianism' (see Kissinger 1994, Mead 2001). Wilson always claimed that American foreign policy must be distinguished from that of the rest of the world by its 'selflessness,' an astonishing claim that, more astonishingly, most Americans at the time accepted as unremarkable. Americans, he said, must have a consciousness different from the consciousness of every other nation in the world, for the force of America, "is the force of moral principle, ...there is nothing else that she loves, and ... nothing else for which she will contend ("Address on the Navy," Wilson 1918a, 101). In his 'making the world safe for democracy' speech when finally taking the nation to war, he insisted that no self-interested motives were or could be at play: "We have no selfish ends to serve. We desire no conquest, no dominion. We seek no indemnities for ourselves, no material compensation for the sacrifices we shall freely make. We are but one of the champions of the rights of mankind" (cited in Link 1954, 282). ${ }^{7}$

In negotiating the peace, Wilson promised an end to what he called the Old Diplomacy of secret dealings and cynical bargains, and to the old balance of power politics that had collapsed so disastrously in war. Balance of power implied force countering force, evil binding evil, a principle that had proved catastrophically unstable in 1914. Wilson would help found a League of Nations in which permanent peace was secured by what he called a 'community of power' undergirded, not by force, but by open agreement to, and respect for, mutually binding principles of law.

Wilson's ultimate failure to get the Treaty of Versailles ratified by Congress induced a mood of profound disillusionment in an America already shaken by hysterical wartime attacks on the civil liberties of insufficiently 'patriotic' citizens (Foner 2000, 177). Americans had also been shocked by French Premier Clemenceau's announcement at the start of the Peace Conference that he intended to be guided throughout by balance of power principles. They were equally dismayed by revelations of Wilson's own secret dealings during negotiations and appalled when he announced a new three-year naval construction program that seemed to undermine the most vital principle of his famous Fourteen Points - disarmament. By the start of

\footnotetext{
${ }^{7}$ British Liberal Prime Minister Lloyd George used such flattering reasoning to cajole Wilson into entering the war, not for the sake of military victory but for the sake of winning the peace. Wilson's judgment, he averred, was the only one among world leaders not corrupted or injured by the war. Only Wilson, being unmotivated by desires for revenge or territory, could hope to impose a just and lasting peace that would properly express the moral value of free government (Gardner 1984, 117-21).
} 
1919, commentators were declaring the League no more than an old-fashioned alliance for power politics as usual (for an extended discussion see Kane 2008, Ch. 9).

Was Wilson tragically sincere, naively self-deluding, hypocritical, Machiavellian, or all of these? Or was he merely unhappily undone trying to straddle an unbridgeable divide between ideal and real? Most instructive on this point was his crucial failure with respect to the 'mutual guaranty' of Article X of the League Covenant, a controversial collective security pledge that committed all members to preventing the aggression of any one of them against any other. The problem was how such aggression was to be prevented. Wilson hoped, absent a global sovereign power, that moral suasion and popular opinion would be sufficient, but Clemenceau was understandably skeptical, and even Wilson was unwilling to put complete faith in the idea. He wanted Article X to be an 'affirmative guaranty,' in other words, an enforcement clause which, by its nature, assumed that the only real deterrent against aggression was the threat or exercise of military power. This implied either a binding commitment of all members to military action or an international force created for that purpose. But this, as Wilson's Secretary of State Robert Lansing clearly saw, would create a ruling group or coalition of great powers that would destroy the equality of members and make "force rather than law, the power to act rather than the right to act ... the fundamental principle of organization" (Lansing 1921, 166-67).

Instead of an ideal organisation built on pure respect for law there would be a political organisation founded simply on fear of sanctions.

Wilson thus found himself trapped between the ideal and the real. He could not persuade himself that the juridical model was workable but was unwilling to accept what had to be done to create one that might work - a firm commitment of American power to the League. He was prepared to contemplate US commitment to force on specific occasions (the implied obligation being merely 'moral' and subject to congressional approval), but would not submit to a legal rule requiring automatic American commitment. This was clearly not strong enough to believably deter future aggressors, but still too strong for Republican senators led by Henry Cabot Lodge whose opposition ultimately doomed ratification of the treaty (Widenor 1980). These senators considered themselves 'realists' opposed to Wilsonian idealism, and refused to compromise even marginally America's sovereign right to decide when its own vital interests were at stake in matters of war.

The irony was that these same senators desired, just as much as Wilson, that the nation should play a responsible role commensurate with its power in world affairs. Yet their strict unilateralism turned into isolationism by default when, in the prevailing post-war atmosphere of disillusionment, the bar for what constituted a vital American interest was set impossibly high (Ambrosius 2002). Despite the rapidly deteriorating international environment of the 1930s, and the failure of the crippled League effectively to address it, the conditions held to justify American intervention were not reached until the Japanese attack on Pearl Harbor. Wilson's defective idealism had found its reaction in an unrealistic realism that proved helpless to prevent another major war.

\section{A Kantian dilemma}

Although I am focusing on American foreign policy here, recall that I do so only to expose a dilemma that affects all liberal democracies in their international relations. This is a consequence, I argue, of a common tendency to assume a stark opposition 
between morality and politics, the origins of which lie (as noted) in Enlightenment thoughts and attitudes. Immanuel Kant was not the sole historical influence here, but his work is the most useful for illuminating its theoretical dimensions, to which I now turn.

Kantian theory posits a gulf between the political and the moral based on a division presumed to exist in all human beings between their 'natural' and their 'higher' selves. The natural self is governed by the passions and is thus deterministically motivated either by force, fear or interest. ${ }^{8}$ Reason operates on this self purely instrumentally to instruct what must be done to fulfill passionate desires. Such instrumental reason issues, in Kant's terminology, in simple 'hypothetical imperatives' of the form "If you want $\mathrm{X}$ do Y." In the higher self, however, reason detaches itself from instrumentality in order to freely choose actions on the basis of their general moral rightness. This pure reason (which Kant called 'practical reason') issues in 'categorical imperatives' of the form "Do Y," which command us independently of whatever we may want.

To the question of what might move a person to obey a categorical imperative, Kant answered that it must be an exercise in pure 'good will.' The good will itself, indeed, generated categorical imperatives by legislating formal, general laws that it would be rationally contradictory to deny. (A famous Kantian example was the moral imperative to tell the truth, it being supposedly rationally contradictory to will as a general law that everyone should lie.) Because both the authority of a universal moral law and one's motive for compliance derived from its pure, formal rationality, moral action escaped the causal determinations of nature and was thus truly free. For Kant, a genuinely moral act was performed neither from a passionate motive of one's own nor for any good end to be achieved, but purely for the sake of freely aligning one's good will with the rational law (Kant 1995, 1999b).

Kant argued that human institutions, although founded on natural motives of interest, fear and caution, are not well and stably founded unless they also inspire genuine moral commitment by virtue of their rational rightness. Force, though effective, is unstable because it provokes resistance and can be countered by opposing force or evasion, ${ }^{9}$ while interests will bind only so long as they remain constant and do not themselves alter. This problem is especially acute in the realm of international relations where no overarching sovereign power exists to enforce norms, where interests constantly shift, and where force is commonly met or balanced by force. Any international organisation dedicated to preserving peace must thus rely to a very large extent on purely moral commitment. Genuine peace would be established, according to Kant, only when human beings had the capacity to act from pure good will upon what their reason instructed was a categorical moral duty not to make war upon one's fellows.

The Kantian structure of Wilson's dilemma over Article X should by now be apparent. A League founded on the threat of force by an association of some powers over others would simply reproduce within the organisation the ordinary tensions of international politics, with no necessary guarantee that great power interests would always align or cooperate. Rather than relying on force, therefore, the ideal League should be founded on pure respect for the rational laws of forbearance that all the members had freely legislated for themselves. The problem with this, as Wilson

\footnotetext{
${ }^{8}$ And one might add, as Kant would, even love, a benevolent passion perhaps, but nevertheless a passion that is not and cannot be a product of our rational will.

${ }^{9}$ As Rousseau, who greatly influenced Kant, wrote: "The strongest man is never strong enough to be master all the time, unless he transforms force into right and obedience into duty" (Rousseau 1968, I, 3).
} 
plainly saw, was that such restraint could hardly be automatically expected among ambitious rivals or determined aggressors. It was a problem which, curiously enough, Kant had already explicitly addressed. He freely admitted that humanity's general moral will, though widely revered, was "impotent in practice" (Kant 1999a). This is, of course, the fundamental assumption of all realist theory, whose normative purpose is also, at base, the prevention of war. Realists, not believing in the force of morality, inevitably rely on forceful mechanisms like balance of power that liberal idealists such as Wilson abhor.

Kant, however, managed to combine an extreme form of realism (of an Augustinian kind that comprehended the incorrigible vanity, folly and wickedness of humankind) with high idealism (that could contemplate the fulfillment of human rational potential in a purely moral community). If such a combination is practically possible then Wilson's fault may have been, not that he was too Kantian, but that he was not Kantian enough. Such a judgment depends, however, on how well we think Kant addressed the question of how his moral ideal might actually be realised in a wicked world. As a matter of fact his solution evoked the necessity of moral progress in history, an idea worth considering here for three reasons: first, because it is not clear that the hopes of modern adherents to democratic peace theory are not also implicitly reliant on such a conception; ${ }^{10}$ second, because the contradictions of Kant's account revealed the unbridgability of the gulf he posited between morality and politics (Hassner 1987); and third, because those same contradictions also pointed, surprisingly, toward the solution of the dilemma of idealism and realism.

It should be noted that Kant searched the historical record more in hope than in confidence. Having inherited Lutheranism's dim view of human nature, he was more circumspect about the possibility of moral progress than some other Enlightenment thinkers. Indeed he did not think moral progress could be proved, but neither did he think it could be disproved; it was our human duty therefore to act as if the possibility were real lest pessimism prove self-fulfilling. "If we assume that humanity never will or can be improved," he wrote, "the only thing which a theodicy seems unable to justify is creation itself, the fact that a race of such corrupt beings ever was on earth" (Kant 1999a). Kant's challenge was to show how creatures whose passionate, empirically-determined natures constantly contradicted and trumped their free moral reason could ever reach the stage of development in which true moral action could be genuinely effectual in political practice. His answer was, curiously, to argue that the moral state would be reached, not through conscious moral action, but by the unseen hand of Nature (or Providence) working through humanity's most selfish and even wicked actions.

In his "Idea for a Universal History" Kant sought to detect the hand of a benevolent Providence at work in the rough processes of nature. He adumbrated a teleological view in which the selfish natural passions that motivated human beings drove them, unbeknown to themselves, toward the moral destiny that their rational nature both made possible and ultimately required. Even the undoubted evil of

\footnotetext{
${ }^{10}$ Of the three 'legs' of the stool on which democratic peace theory rests (Doyle1986), two seem to rely principally on worldly motives - the mutual advantages and interdependencies generated by commerce and the reluctance of democratic citizens to bear the costs and hardships of war. However, the third, adherence to a federation under international law seems to remain dependent, absent a world government, on a sufficient fund of good will among nations. Also, assumptions are usually made that, as nations become democratic, their citizens "internalise or are 'socialised' into pacific liberal-democratic values presumed to be more than merely instrumental. Certainly democratisation literature always greets the downfall of tyrants and the establishment of more democracies as moral progress.
} 
warfare was seen as Nature's instrument for forcing humanity onwards: "Man wishes concord; but Nature knows better what is good for the race; she wills discord. He wishes to live comfortably and pleasantly; Nature wills that he should be plunged from sloth and passive contentment into labour and trouble, in order that he may find means of extricating himself from them" (Kant 1963). From perpetual war would arise the possibility of perpetual peace, and the foundation of this would be the increasing establishment of free republican governments capable at length of forming a federation to safeguard peace under international law.

The idea that private vice could lead to public benefit went back to Bernard Mandeville in the seventeenth century, and versions of it were also argued by contemporaries of Kant like Hume and Adam Smith. But Smith's and Hume's views were not incompatible with their naturalistic moral theories, founded in 'sentiments' or passions that they believed alone could move human beings to act. Hume had assumed that the function of moral sentiments, rules and actions, and the ground of their ultimate justification, lay in the support they provided for human sociability and happiness (Hume 1975, 305). But Kant's radical deontology implied, as we have seen, a deep disjunction between morality and nature that meant even actions promoting the general happiness (including the abolition of war) could not be properly moral. It was therefore deeply paradoxical that he should have to rely on people's amoral natures to lay the groundwork on which truly moral political action became possible. Kant gave a very Hobbesian account of humanity's emergence from the state of nature, with people's desire for safety and comfort in a world of permanent enmity, distrust and conflict prompting them to form 'civilised' constitutional republics. In such republics peace was enforced through fear of law and the magistrate's sword rather than through moral virtue. Kant hoped, nevertheless, that under free constitutions citizens might learn genuine respect for law as such, inclining them to conform their wills appropriately. This was indeed an essential precondition for establishing an international federation of republics that would be capable of securing peace even though lacking any supreme enforcing authority.

Had Woodrow Wilson dwelt on these Kantian ideas he might have concluded that his own hopes for an ideal international organisation were not absurd, merely premature. Certainly the idea of Providence was not strange to American minds, being firmly embedded in their national myth. Wilson himself thought he detected the hand of Providence in the terrible European war whose termination gave America the opportunity to fulfill its historic mission of peace. Moreover, the possibility that Providence might move in mysterious, counterintuitive ways seemed confirmed in American history by the Civil War, which removed the dark blot of slavery from America's proud banner of liberty - a result more "fundamental and astounding," as Lincoln said, because never intended by either party. ${ }^{11}$ Wilson acknowledged in his history of the United States that this war had fundamentally changed America. "All things," he wrote, "took their hue and subtle transformation from it: the motives of politics, the whole theory of political action, the character of the government, the sentiment of duty, the very ethics of private conduct were altered as no half century of slow peace could have altered them (Wilson 1918b, III, 121; my emphasis). In other words, neither the nation's highest ideals nor its revered Constitution had, just by their existence, been able to secure a Union that was proclaimed 'the last best hope of earth.' The American moral community was forged, finally, through conflict and the

\footnotetext{
${ }^{11}$ This is a major democratic war ignored by democratic peace theory - no doubt on the technical ground that it was 'civil'; the Constitution promulgated by the Confederacy was almost identical to that of the United States, but unburdened by the Declaration of Independence's claim of natural human equality.
} 
coercive application of Northern will on a South that remained, for long afterwards, merely bitterly acquiescent.

Of course the myth of inevitable, providential progress retains little intellectual respectability in our thought today (however much its residues may pervade our collective consciousness). It is one thing to argue that out of evil may come some genuine good, or that conditions must be ripe before any progressive good can be realised, it is quite another to impose a teleological pattern on events. Many outcomes may be unanticipated and unintended, but if any lasting good is to be achieved it must be through conscious and intelligent action on the opportunities presented by particular circumstances. Lincoln may have intended to preserve the Union, not free the slaves, but they were freed in the end by his own canny and careful political adaptation to circumstances that had been radically altered by his own attempt to save the Union. Progress can only be a result, in other words, of judgements and actions founded in careful political prudence.

But this observation points us to the central problem with the Kantian account of morality and politics, namely its failure to adumbrate a satisfactory account of prudential action. The latter is the only feasible solution to the dilemma of idealism and realism, and it was ironically implicit (though seldom noticed) in Kant's own account. Kant needed political prudence to convincingly connect moral reason and political action, but his theory of morality was utterly unable to accommodate it. It is to this vital issue that I now turn. ${ }^{12}$

\section{Political prudence}

Kant wrote in 'Perpetual Peace':

If there is no freedom and no morality based on freedom, and everything which occurs or can occur happens by the mere mechanism of nature, certainly politics (which is the art of using this mechanism for ruling men) is the whole of practical wisdom, and the concept of right is an empty thought. But if we find it necessary to connect the latter with politics, and even to raise it to a limiting condition thereon, the possibility of their being united must be conceded (Kant 1999).

He went on to declare it quite believable that a 'moral politician' might base political principles on moral ones, but distinguished such a figure from what he called a 'political moralist,' who cynically elaborates quasi-moral positions to gain political advantage. But his more interesting distinction is between the moral politician and the moral zealot, or as he terms it, the 'despotizing moralist' who, "in practice blundering, often violate rules of political prudence through measures they adopt or propose too precipitately; but experience will gradually retrieve them from their infringement of nature and lead them on to a better course" (Kant 1999). The wise moral politician, on the other hand, knows that:

\footnotetext{
${ }^{12}$ Hiram Caton $(1970,37)$ remarked in a footnote that "To my knowledge no commentator has noticed the crucial role Kant assigns to prudence, even as he condemns it as immoral." Since then Elizabeth Ellis $(2005,2008)$ has pursued a theory of what she calls 'provisional politics' derived from Kant's political writings which is really a theory of political prudence, though she never names it such, and seems not to notice Caton's point about its 'immorality.'
} 
...it would be absurd to demand that every defect be immediately and impetuously changed, since the disruption of the bonds of a civil society or a union of world citizens before a better constitution is ready to take its place is against all politics agreeing with morality. But it can be demanded that at least the maxim of the necessity of such a change should be taken to heart by those in power, so that they may continuously approach the goal of the constitution that is best under laws of right (Kant 1999).

But this introduces a consideration of political prudence that considerably modifies the absolute nature of Kantian categorical imperatives. Such a concession is problematic because everywhere else in Kant's work prudence is denied moral status: it cannot be moral because always in the service of particular interests or ends. In 'Perpetual Peace' he writes that if by 'ethics we mean a general doctrine of prudence, [this] would be the same as a theory of the maxims for choosing the most fitting means to accomplish the purposes of self-interest. But to give this meaning to ethics is equivalent to denying that there is any such thing at all" (Kant 1999). Yet to acknowledge that sound judgment is required to determine when and how far circumstances may permit a sincerely held moral rule to be safely applied is to give much crucial ground to prudence. If to act with moral impetuosity in unpromising conditions "is against all politics agreeing with morality," then to act prudently in such conditions must be in agreement with morality. This implies a status for prudent practical judgment that is clearly superior to mere self-interested calculation.

Kant struggles with this dilemma in Appendix 1 of 'Perpetual Peace,' but the results are unsatisfactory and ultimately contradictory. He criticises pragmatic principles ("material principles" that depend on "the end as the object of choice") because they imply merely technical solutions that, moreover, demand a knowledge of prior causes and future consequences beyond our capacity to master. He wishes rather to defend the ultimate practicality of the pure moral act, divorced not only from any personal motive but from any good end to be achieved. Moral evil, he says, has the "property of being opposed to and destructive of its own purposes" (a proposition that seems plainly contradictory of his claim that the grounds for proper morality must be prepared by the non-moral motives and actions of natural humanity). Pure principles, on the other hand, though not aiming at good ends but rather at pure duty, will providentially also achieve the good ends. Thus, he says, "it may be said, 'Seek ye first the kingdom of pure practical reason and its righteousness, and your end (the blessing of perpetual peace) will necessarily follow'." But even if the formal principle of pure reason "leads directly to the end," as he says, "remembering discretion, it does not precipitately hasten to do so by force; rather, it continuously approaches it under the conditions offered by favourable circumstances." But here we are back again with prudent 'discretionary' judgment of 'favourable circumstances,' which cannot be moral because not formally derivable from a priori reason yet upon which successful application of moral principles clearly depends.

In Appendix 1 Kant fails to disentangle self-serving action from principled pragmatic action. His argument continually confuses and conflates the two, as indeed it must when morality has been so radically divorced from the world in which it is supposed to be active. Kant's stringent view of morality disables, in the end, the capacity for making genuinely ethical distinctions, for an act done sincerely for some good end is no more moral than one done from an evil motive. Moreover, the distinction Kant does make between categorical moral imperatives (derived from pure reason) and hypothetical non-moral ones (derived from pragmatic judgment) tends to 
reduce morality to a choice between selfless and self-interested action (even if this is not logically implied). Kant himself does not avoid this reduction as we have seen in his comments on prudence. This is problematic, not just because it misleadingly equates self-interest with selfishness, but also because it is not at all clear that responsible action conscientiously performed in the world is best described as 'selfless.' A statesmanlike action - Lincoln's eventual emancipation of the slaves may accord with moral principles long held yet hitherto judged imprudent to act upon - slavery is wrong - yet in what sense are we enlightened, or even correct, in calling this action 'selfless?' It is an example, rather, of principled prudential action of the sort that Kant himself admitted was necessary, but which his moral theory had no means of accommodating.

And this brings us back to the Kantian dilemma of Woodrow Wilson, in which acting on behalf of an ideal League seemed bound to fail in practice while acting in accord with worldly realities seemed bound to fail morally (and ultimately practically as well). Wilson's real failure was not that he did not achieve a Kantian federation that would end war, but that he did not achieve what he might have done in the circumstances. He stubbornly fought the battle for ratification as though it were an allor-nothing affair, but he had already foregone the 'all' (the Kantian League), and his final position was not far distant from that of Lodge, making compromise possible (Widenor 1980; Ambrosius 2002). It was, above all, a failure of political prudence that kept America out of the League, causing that organisation to be virtually stillborn and thus incapable of weathering, never mind taming, the international storms that later blew destructively across the planet.

\section{Conclusion}

I have argued that the American example illustrates how and why liberal democratic foreign policies tend to confront a dilemma of idealism versus realism. Shining ideals, almost by definition, will be tarnished by contact with the world, and too zealous a pursuit of them is likely to be highly counterproductive. Purely cynical action based on so-called realistic grounds, on the other hand, will be properly condemned as morally bankrupt. The possibility of genuinely ethical action requires a statesmanlike understanding of decent ends to be achieved combined with a realistic assessment of what the world will currently allow, as well as an alert preparedness to take advantage of opportunities for improvement as they occur. It requires, in other words, a genuine realism that does not dispense with the moral perspective but finds it embodied in attitudes of practical political wisdom. Which is not to say that pursuing a prudent foreign policy is easy. The world is complicated and unmanageable even by great powers, making prudential judgement and action both necessary and difficult.

Prudential actions are also commonly subject to democratic misunderstanding, as the Obama administration's experience shows. Obama's foreign policy team saw its task as putting America back on course after what it regarded as the disastrously hubristic, incompetent, divisive and morally reprehensible performance of the Bush administration. It emphasised reaching out and being prepared to talk to enemies rather than insulting and confronting them - and was predictably assaulted by the Right for showing weakness, especially when no immediate payoff was observed. It tried to deal respectfully with non-democracies, especially China, without preaching democracy and human rights - and was predictably attacked from the Left for making liberal democratic values subservient to economic interests. Obama assured European 
nations that the United States did not assume automatic superiority over others - and was predictably denigrated for not believing in 'American exceptionalism.'

Most instructive was the reaction to Obama's decision to support the antiGadaffi rebels in Libya. This presented peculiar difficulties for any American administration, as did all the challenges of the 'Arab Spring.' The United States had, for 'realistic' reasons, effectively supported Arab dictators for many decades, but no American administration could possibly appear to oppose or condemn popular uprisings against those same dictators. The Obama administration's support for various risings was offered with incremental caution, and it responded to charges of inconsistency by making the prudential case that different circumstances in different countries demanded differential, if always sympathetic, responses.

When pressed by its European allies to play a role in Libya, it took to heart the negative lessons of the Bush experience in Iraq. Secretary of Defense Robert Gates argued that no vital US national interests were at stake, explicitly placing limits on the costs America would bear. Obama made US involvement conditional on: the existence of a local resistance movement willing and able to take on Gadaffi; on the express support of some Arab countries; on a stamp of legitimacy from a UN Security Council Resolution; and on NATO allies taking primary responsibility after an initial degrading of Gadaffi's assets by US forces. But as time passed and a messy civil war developed, with no clear end in sight, Obama was ridiculed for his attempt to 'lead from behind.' He was attacked from the Right for needless involvement in a war that served no important American interests, and from the Left for not escalating the US effort and ensuring the swift victory of aspiring democrats over a dictator. When the Gadaffi regime was eventually toppled - with whatever uncertain consequences for the future but at least believably as the result of indigenous desires and actions critics on both sides went uncomfortably quiet.

It is undoubtedly problematic that the wisdom of prudential judgements may not become apparent until long afterward, making them vulnerable to political demands of immediacy. Because they aim at the best possible outcomes, all things considered, they are not usually easily pigeonholed in partisan terms and are liable to elicit opportunistic critique by either side in an ideologically divided polity.

Bandstanding slogans that invoke traditional tropes - 'strength and interests' on the one side, 'moral imperatives' on the other - elicit instant responses, whereas explaining the complexities of prudential decisions taxes even patient constituents. It will therefore always be difficult for liberal democratic leaders to escape the gravitational pull of the realism-idealism divide.

Yet fostering a culture in which political prudence is at least possible offers the only feasible strategy for dealing with the traditional dilemma. Whether the possible becomes actual depends, inevitably and ineffably, on the quality of the people in the position to make consequential judgments. How they might execute the necessary task of formulating and politically defending a truly prudential foreign policy that can gain popular support remains an important question for another day.

\section{References}

Ambrosius, Lloyd E. 2002, Wilsonianism: Woodrow Wilson and His Legacy in American Foreign Relations, New York: Palgrave Macmillan. 
Appleby, Joyce, Lynn Hunt and Margaret Jacob 1995, Telling the Truth About History, New York: Norton.

Carnegie, Andrew 1933, Miscellaneous Writings of Andrew Carnegie, 2 vols., edited by Burton J. Hendrick, Garden City, NY: Doubleday, Doran \& Co.

Claude, Inis L., 1986, "The common defense and great power responsibilities," Political Science Quarterly, 101(5): 719-32.

Commager, Henry Steele 1977, The Empire of Reason: How Europe Imagined and America Realized the Enlightenment, Garden City, NY: Anchor Press/Doubleday.

Doyle, Michael 1983, "Kant, Liberal Legacies and Foreign Affairs," Parts 1 and 2, Philosophy and Public Affairs 12: 205-235, and 323-353.

Doyle Michael 1986, "Liberalism and World Politics," American Political Science Review 80: 1151-69.

Dumbrell, John 1995, The Carter Presidency: A Re-evaluation, Manchester: Manchester University Press.

Ellis, Elizabeth 2005, Kant's Politics: Provisional Theory for an Uncertain World, New Haven: Yale University Press.

Ellis, Elizabeth 2008, Provisional Politics: Kantian Arguments in Policy Context, New Haven: Yale University Press.

Foner, Eric 2000, The Story of American Freedom, London: Papermac.

Galston, William 1975, Kant and the Problem of History, Chicago: University of Chicago Press.

Gardner, Lloyd C. 1984, Safe for Democracy: The Anglo-American Response to Revolution, 1913-1923, New York: Oxford University Press.

Hume, David 1975 [1751], Enquiry concerning the Principles of Morals, edited by L. A. Selby-Bigge, 3rd edition revised by P. H. Nidditch, Oxford: Clarendon Press.

Kane, John 2008, Between Virtue and Power: The Persistent Moral Dilemma of U.S. Foreign Policy, New Haven: Yale University Press.

Kant, Immanuel 1963 [1784], Idea for a Universal History from a Cosmopolitan Point of View (1784), trans. by Lewis White Beck, from Immanuel Kant, "On History," Indianapolis, IN: Bobbs-Merrill Co. (online transcribed by Rob Lucas: (http://www.marxists.org/reference/subject/ethics/kant/universal-history.htm\#n1).

Kant, Immanuel 1995 [1785], Foundations of the Metaphysics of Morals, Upper Saddle River NJ: Prentice Hall. 
Kant, Immanuel 1999a [1795], Perpetual Peace: A Philosophical Sketch, South Hadley, MA: Mount Holyoke College

(http://www.mtholyoke.edu/acad/intrel/kant/kant1.htm -- accessed 14 June 2011)

Kant, Immanuel 1999b [1788], Critique of Practical Reason, New York: Maxwell Macmillan International.

Kissinger, Henry 1994, Diplomacy, New York: Simon \& Schuster.

Lansing, Robert 1921, The Peace Negotiations: A Personal Narrative, Boston: Houghton Mifflin.

Link, Arthur S. 1954, Woodrow Wilson and the Progressive Era, 1910-1917, New York: Harper and Row.

Mead, Walter Russell 2001, Special Providence: American Foreign Policy and How it Changed the World, New York: Alfred A. Knopf.

Morgenthau, Hans J. 1948, Politics Among Nations: The Struggle for Power and Peace, New York: A.A. Knopf.

Morgenthau, Hans J. 1951, In Defense of the National Interest: A Critical Examination of American Foreign Policy, New York: A.A. Knopf.

Morgenthau, Hans J. 1965, Vietnam and the United States, Washington, DC: Public Affairs Press.

Niebuhr, Reinhold 1932, Moral Man and Immoral Society: A Study in Ethics and Politics, New York: C. Scribner's Sons.

Osgood, Robert Endicott 1953, Ideals and Self-Interest in America's Foreign Relations: The Great Transformation of the Twentieth Century, Chicago: University of Chicago Press.

Rousseau, Jean- Jacques 1968, The Social Contract, Harmondsworth: Penguin.

Runciman, David 2008, Political Hypocrisy: The Mask of Power, from Hobbes to Orwell and Beyoond, Princeton: Princeton University Press.

Seward, William H. 1853-4, The Works of William H. Seward, George E. Baker, ed., New York: Redfield.

Widenor, William C. 1980, Henry Cabot Lodge and the Search for an American Foreign Policy, Berkeley: University of California Press.

Wills, Garry 1987, Reagan's America: Innocents at Home, New York: Doubleday.

Wilson, Woodrow 1918a, President Wilson's Foreign Policy: Messages, Addresses, Papers, edited by James Brown Scott, New York: Oxford University Press. 
Wilson, Woodrow 1918b, A History of the American People, Vol. VIII, New York: Harper \& Brothers. 